INTERNATIONAL JOURNAL OF INNOVATION IN ENTERPRISE SYSTEM

Journal homepage: https://ijies.sie.telkomuniversity.ac.id e-ISSN: 2580-3050, DOI: https://doi.org/10.25124/ijies.v6i01.139

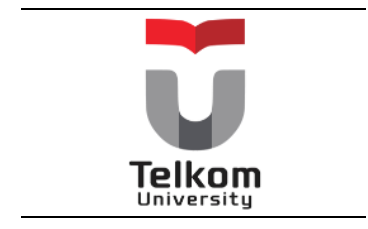

\title{
The Project Performance Evaluation of PLBN Project Using Earned Value Management Method
}

\author{
Malsya Debrina Nur Salsabila ${ }^{1^{*}}$, Ika Arum Puspita ${ }^{2}$, Sandhy Widyasthana ${ }^{3 *}$
}

${ }^{1}$ School of Industrial and System Engineering

Telkom University, Bandung, Indonesia

malsyadn@student.telkomuniversity.ac.id

${ }^{2}$ School of Industrial and System Engineering

Telkom University, Bandung, Indonesia

ikaarumpuspita@telkomuniversity.ac.id

${ }^{3}$ School of Industrial and System Engineering

Telkom University, Bandung, Indonesia

widyasthana@gmail.com

*malsyadn@student.telkomuniversity.ac.id

ARTICLE INFO

Article history:

Received 19 July 2021

Accepted 28 July 2021

Published 31 January 2022

\section{ABSTRACT}

Process of monitoring and controlling projects requires data evaluation activities in the order to find out whether the project is in accordance with the plan to avoid an incompatibility between the planning and the actual time. The failure of construction project almost reached the figure of $20 \%$ $40 \%$ which occurred in the project monitoring and controlling process. The purpose of this research is analysis project performance with earned value management method at PLBN Project. This research was carried out by several stages: data collection, data processing and analysis. From the results of the performance index analysis show that the project's performance on the construction project is still not good. At week 16 the CPI and SPI values are 0.94 and 0.85 . Both values can be interpreted that the costs incurred are greater than planning and the implementation time is longer than planning. The result of EAC is Rp. 2.423.695.294 with an estimated completion time is 21 weeks which indicates that there is an additional 3 weeks of completion.
Keywords:

Project Monitoring and

Controlling; Earned Value

Management; CPI; SPI;

Project Performance

\section{INTRODUCTION}

The project is an activity that is limited by time and resources in the form of humans, costs, materials and equipment that produces a product, service and result. Project need a good and correct project management to manage a project from the initial to the final stage [1]. A construction project is a project that has unique characteristics. The process carried out in each construction project will have various kinds of differences caused by conditions that occur during project implementations. This has resulted in the constructions project being one of the project with largest failure rate [2]. The failure of construction project almost reached the figure of $20 \%-40 \%$ which occurred in the project monitoring and controlling process. 
The process carried out in each construction project will have various kinds of differences caused by conditions that occur during project implementations. This has resulted in the constructions project being one of the project with largest failure. The factors that cause the process monitoring and controlling being the reason for the failure of construction projects are the use of systems that are still completely manual. Another factor is that some companies are currently ignoring the use of methods that can support the project management process, especially at the stage of project monitoring and controlling [3]. Project monitoring and controlling is a stage in project management process that is carried out after the project is successfully executed. The process of project monitoring and controlling is carried out to monitor project progress and manage each project activity by comparing plans with actual conditions. This is done the aim that the project can be completed in accordance with the plans that have been made [4]. Several components that need to be considered in the process of monitoring and controlling in achieving a goal are cost, time and scope of work [1].

In project implementation at one of the contractor company does not use the methods contained in project management and does not yet have an information system to carry out the monitoring and controlling process that caused the company often gets problems, one of which is an incompatibility between planning and actual time. In 2011, the company is working on a penstock project which has been delayed for 90 days and there is a penalty of Rp. 1.624.284.360 of the planned costs.

Currently, the company is working on a construction project (PLBN) with a limit of 18 weeks starting from January May 2021. PLBN project undertaken by the company has entered the project monitoring and controlling phase where at this time the company has not used the method project management and does not have an information system to support the process of project monitoring and controlling which results in a lack of information regarding project performance that has been carried out to date.

The purpose of this research is to analysis project performance with earned value management at construction project using spreadsheet-based dashboard tools.

\section{METHOD}

Research method of this research is shown in the Figure 1.

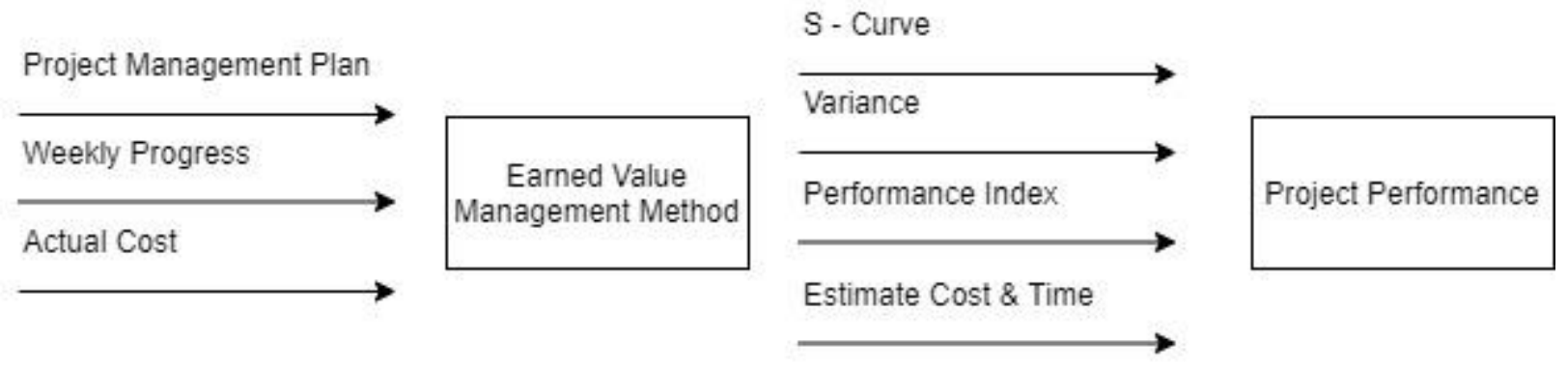

Figure 1 - Research Method

Research method is showed at Fig.1, the data needed in this research is a project management plan consisting of a project charter, work breakdown structure, project plan and budget plan, weekly progress and actual cost. After the data has been collected, the next step is to process the data using the spreadsheet-based dashboard which is carried out according to the earned value management equations with several calculations, namely the calculation of variance, calculation of performance index and calculation of estimated time and cost. the result of data processing from this research is project performance.

\subsection{Project Charter}

Project charter is a document that states and explains that there is a project. The project charter document contains the description, objectives, limits, deliverables and project milestones. Project charter of this research is shown on the Table 1.

Table 1 - Project Charter

PROJECT CHARTER

\begin{tabular}{ll}
\hline Project Name & PLBN Project \\
\hline Company & Contractor Company \\
\hline Project Time & 18 Weeks (1 January - 16 May 2021) \\
\hline Deliverables & Building \\
\hline Project Manager & Lambok Manik
\end{tabular}


PROJECT IDENTIFICATION

\begin{tabular}{ll}
\hline & PLBN Project is construction project that build an area that has \\
Project Description & several buildings including bridge buildings, main buildings \& \\
& guesthouses and dormitories, site development buildings, office \\
& buildings and water tower buildings.
\end{tabular}

Project Goals

The purpose of this project is the construction of a National Border Post (PLBN) in the North Kalimantan area which is useful for crossborder security between Indonesia and foreign countries.

The scope of work starts from material procurement, material fabrication, material delivery, installation in the field and other provisions that have been explained during clarification and

Project Boundaries negotiation.

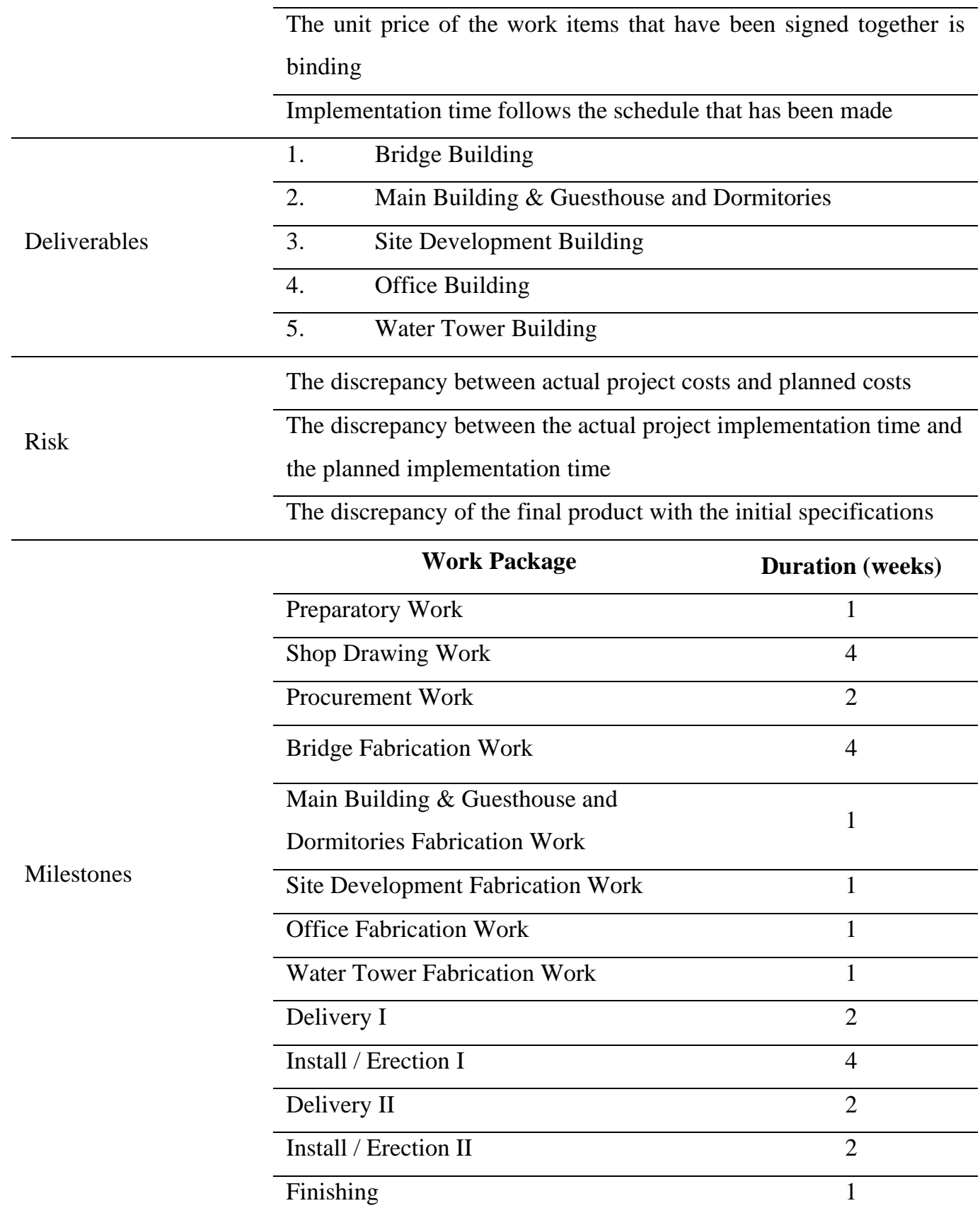




\subsection{Work Breakdown Structure}

Work Breakdown Structure (WBS) is an organized list of activities of the overall scope of work to be carried out to achieve project objectives. WBS is used to break down or break down project work activities into more detailed processes so that they are easier to manage. WBS of this research is shown in Figure 2.

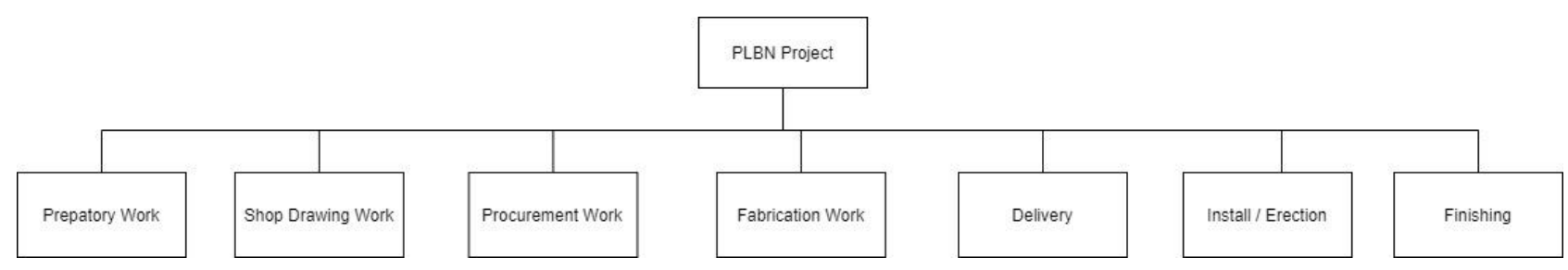

Figure 2 - Work Breakdown Structure

\subsection{Project Schedule Plan}

Table 2 is the schedule planning data owned by the construction project as a reference in project work. There is information about the duration planning for each activity in the construction project, besides that there is a predecessor activity in each project activity which is called a predecessor.

Table 2 - Project Schedule Plan

\begin{tabular}{|c|c|c|c|c|}
\hline No & Work Description & Activity & Predecessor & $\begin{array}{l}\text { Duration } \\
\text { (weeks) }\end{array}$ \\
\hline \multicolumn{5}{|c|}{ Project Planning } \\
\hline 1 & $\begin{array}{l}\text { Carry out the process of preparing project } \\
\text { time planning }\end{array}$ & A & - & 1 \\
\hline 2 & $\begin{array}{l}\text { Carry out the process of preparing project } \\
\text { cost planning }\end{array}$ & B & - & 1 \\
\hline \multicolumn{5}{|c|}{ Project Shop Drawing } \\
\hline 3 & Carry out the shop drawing process I & $\mathrm{C}$ & A,B & 4 \\
\hline 4 & Carry out the shop drawing process II & $\mathrm{D}$ & A,B & 4 \\
\hline \multicolumn{5}{|c|}{ Material Procurement } \\
\hline 5 & $\begin{array}{l}\text { Carry out the material procurement } \\
\text { process I }\end{array}$ & $\mathrm{E}$ & $\mathrm{A}, \mathrm{B}$ & 2 \\
\hline 6 & $\begin{array}{l}\text { Carry out the material procurement } \\
\text { process II }\end{array}$ & $\mathrm{F}$ & A,B & 2 \\
\hline \multicolumn{5}{|c|}{ Bridge Fabrication } \\
\hline 7 & $\begin{array}{l}\text { Carry out structural work for bridge } \\
\text { buildings }\end{array}$ & G & A,B & 4 \\
\hline 8 & $\begin{array}{l}\text { Carry out architecture work for bridge } \\
\text { buildings }\end{array}$ & $\mathrm{H}$ & A,B & 4 \\
\hline
\end{tabular}

Main Building \& Guesthouse and Dormitories Fabrication

Carry out structural work processes for

9 main buildings \& guesthouses and

I E,F

1

dormitories 
Carry out architecture work processes for

10 main buildings \& guesthouses and dormitories

\section{Site Development Fabrication}

11 Carry out the process of structural work for site development buildings

K

Carry out the process of architecture

12

work for site development buildings

Carry out the process of working on the

13 outer fence for the completeness of the site development building

\section{Office Building Fabrication}

\begin{tabular}{lllll}
\hline 14 & $\begin{array}{l}\text { Carrying out the process of structural and } \\
\text { roof work for office buildings }\end{array}$ & $\mathrm{N}$ & $\mathrm{K}, \mathrm{L}, \mathrm{M}$ & 1 \\
15 & $\begin{array}{l}\text { Carrying out the process of architecture } \\
\text { and roof work for office buildings }\end{array}$ & $\mathrm{O}$ & $\mathrm{K}, \mathrm{L}, \mathrm{M}$ & 1
\end{tabular}

\begin{tabular}{|c|c|c|c|c|}
\hline \multicolumn{5}{|c|}{ Water Tower Fabrication } \\
\hline 16 & $\begin{array}{l}\text { Carry out the process of structural work } \\
\text { for water tower buildings }\end{array}$ & $\mathrm{P}$ & $\mathrm{N}, \mathrm{O}$ & 1 \\
\hline 17 & $\begin{array}{l}\text { Carry out the process of architecture } \\
\text { work for water tower buildings }\end{array}$ & Q & $\mathrm{N}, \mathrm{O}$ & 1 \\
\hline \multicolumn{5}{|c|}{ Material Delivery } \\
\hline 18 & $\begin{array}{l}\text { Carry out the delivery process I from the } \\
\text { workshop to Site }\end{array}$ & $\mathrm{R}$ & $\mathrm{I}, \mathrm{J}$ & 2 \\
\hline 19 & $\begin{array}{l}\text { Carry out the delivery process II from the } \\
\text { workshop to Site }\end{array}$ & $\mathrm{S}$ & $\mathrm{I}, \mathrm{J}, \mathrm{T}$ & 2 \\
\hline
\end{tabular}

\section{Material Install / Erection}

\begin{tabular}{|c|c|c|c|c|}
\hline 20 & $\begin{array}{l}\text { Carry out the installation / erection I } \\
\text { process in Site }\end{array}$ & $\mathrm{T}$ & $\mathrm{K}, \mathrm{L}, \mathrm{M}$ & 4 \\
\hline 21 & $\begin{array}{l}\text { Carry out the installation / erection I } \\
\text { process in Site }\end{array}$ & $\mathrm{U}$ & $\mathrm{S}$ & 2 \\
\hline \multicolumn{5}{|c|}{ Project Closing } \\
\hline 22 & $\begin{array}{l}\text { Carry out the project handover process } \\
\text { between the project owner and the project } \\
\text { manager }\end{array}$ & $\mathrm{V}$ & $\mathrm{U}$ & 1 \\
\hline 23 & $\begin{array}{l}\text { Carry out the process of archiving project } \\
\text { documents for company needs }\end{array}$ & W & $\mathrm{U}$ & 1 \\
\hline
\end{tabular}




\subsection{Budget Plan}

Budget plan a document that contains an estimated budget that will be issued for all forms of needs during the implementation of the $\mathrm{ABC}$ project work. Budget plan of this research is shown in Table 3.

Table 3 - Budget Plan

\begin{tabular}{|c|c|c|c|c|c|c|c|}
\hline No & Work Description & Qty & Volume & \multicolumn{2}{|c|}{ Unit Price } & \multicolumn{2}{|r|}{ Budget } \\
\hline \multirow{2}{*}{1} & Project Time Planning & Ls & 1 & $\mathrm{Rp}$ & 2.500 .000 & $\mathrm{Rp}$ & 2.500 .000 \\
\hline & Project Cost Planning & Ls & 1 & $\mathrm{Rp}$ & 2.500 .000 & $\mathrm{Rp}$ & 2.500 .000 \\
\hline \multirow[t]{3}{*}{2} & Project Shop Drawing & & & & & & \\
\hline & Shop Drawing I & Ls & 1 & $\mathrm{Rp}$ & 10.000 .000 & $\mathrm{Rp}$ & 10.000 .000 \\
\hline & Shop Drawing II & Ls & 1 & $\mathrm{Rp}$ & 10.000 .000 & $\mathrm{Rp}$ & 10.000 .000 \\
\hline \multirow[t]{3}{*}{3} & Material Procurement & & & & & & \\
\hline & Material Procurement I & Ls & 1 & $\mathrm{Rp}$ & 55.000 .000 & $\mathrm{Rp}$ & 55.000 .000 \\
\hline & Material Procurement II & Ls & 1 & $\mathrm{Rp}$ & 95.000 .000 & $\mathrm{Rp}$ & 95.000 .000 \\
\hline \multirow[t]{3}{*}{4} & Bridge Fabrication & & & & & & \\
\hline & $\begin{array}{l}\text { Bridge Structural and Roofing } \\
\text { Work }\end{array}$ & $\mathrm{m}$ & 3500,00 & $\mathrm{Rp}$ & 150.000 & $\mathrm{Rp}$ & 525.000 .000 \\
\hline & Bridge Architecture Work & $\mathrm{m}$ & 2500,68 & $\mathrm{Rp}$ & 100.000 & $\mathrm{Rp}$ & 250.068 .000 \\
\hline
\end{tabular}

5

Main Building \& Guesthouse

\begin{tabular}{|c|c|c|c|c|c|c|c|}
\hline & $\begin{array}{l}\text { Main Building \& Guesthouse } \\
\text { and Dormitory Structure Work }\end{array}$ & $\mathrm{m}$ & 507,12 & $\mathrm{Rp}$ & 150.000 & $\mathrm{Rp}$ & 76.068 .000 \\
\hline & $\begin{array}{l}\text { Main Building \& Guesthouse } \\
\text { and Dormitory Architecture } \\
\text { Work }\end{array}$ & $\mathrm{m}$ & 125,12 & $\mathrm{Rp}$ & 100.000 & $\mathrm{Rp}$ & 12.512 .000 \\
\hline \multirow[t]{4}{*}{6} & Site Development Fabrication & & & & & & \\
\hline & $\begin{array}{l}\text { Site Development Structure } \\
\text { Work }\end{array}$ & $\mathrm{m}$ & 70,18 & $\mathrm{Rp}$ & 150.000 & $\mathrm{Rp}$ & 10.527 .000 \\
\hline & Portal Gate Work & Ls & 1 & $\mathrm{Rp}$ & 12.230 .250 & $\mathrm{Rp}$ & 12.230 .250 \\
\hline & Outer Fence Work & Ls & 1 & $\mathrm{Rp}$ & 204.482 .500 & $\mathrm{Rp}$ & 204.482 .500 \\
\hline \multirow[t]{3}{*}{7} & Office Fabrication & & & & & & \\
\hline & $\begin{array}{l}\text { Office Structural and Roofing } \\
\text { Work }\end{array}$ & $\mathrm{m}$ & 150,57 & $\mathrm{Rp}$ & 150.000 & $\mathrm{Rp}$ & 22.585 .500 \\
\hline & Office Architecture Work & $\mathrm{m}$ & 112,67 & $\mathrm{Rp}$ & 100.000 & $\mathrm{Rp}$ & 11.267 .000 \\
\hline \multirow[t]{3}{*}{8} & Water Tower Fabrication & & & & & & \\
\hline & Water Tower Structural Work & $\mathrm{m}$ & 167,89 & $\mathrm{Rp}$ & 150.000 & $\mathrm{Rp}$ & 25.183 .500 \\
\hline & Water Tower Architecture Work & $\mathrm{m}$ & 136,89 & $\mathrm{Rp}$ & 100.000 & $\mathrm{Rp}$ & 13.689 .000 \\
\hline \multirow[t]{3}{*}{9} & Material Delivery & & & & & & \\
\hline & Delivery I & $\mathrm{Kg}$ & 51777,93 & $\mathrm{Rp}$ & 500 & $\mathrm{Rp}$ & 25.888 .965 \\
\hline & Delivery II & $\mathrm{Kg}$ & 224373,89 & $\mathrm{Rp}$ & 500 & $\mathrm{Rp}$ & 112.186 .943 \\
\hline \multirow[t]{3}{*}{10} & Material Install / Erection & & & & & & \\
\hline & Install / Erection I & $\mathrm{Kg}$ & 51777,93 & $\mathrm{Rp}$ & 2.500 & $\mathrm{Rp}$ & 129.444 .825 \\
\hline & Install / Erection II & $\mathrm{Kg}$ & 224373,89 & $\mathrm{Rp}$ & 2.500 & $\mathrm{Rp}$ & 560.934 .715 \\
\hline
\end{tabular}




\begin{tabular}{llllllll}
\hline 13 & Project Closing & & & & & \\
\hline & Handover Project & Ls & 1 & $\mathrm{Rp}$ & 2.500 .000 & $\mathrm{Rp}$ & 2.500 .000 \\
& Project Document Archive & $\mathrm{Ls}$ & 1 & $\mathrm{Rp}$ & 2.500 .000 & $\mathrm{Rp}$ & 2.500 .000 \\
\hline & Total Budget & & & & $\mathrm{Rp}$ & 2.172 .068 .198 \\
\hline
\end{tabular}

\section{RESULT AND DISCUSSION}

The results of data processing using a spreadsheet-based dashboard with the concept of earned value management as a tool are as follows:

\subsection{PV EV AC}

Calculation of PV, EV and AC using the spreadsheet-based dashboard which is carried out according to the earned value management equations. Actual Cost value is obtained from direct costs and indirect costs over a certain period of time. Table 4 are the results of PV, EV and AC using a spreadsheet-based dashboard in the 1st week to 16th week period:

Table 4 - PV EV AC

\begin{tabular}{|c|c|c|c|c|c|c|}
\hline Week & PV & PV Cumulative & EV & EV Cumulative & AC & AC Cumulative \\
\hline 1 & Rp5.000.000 & Rp5.000.000 & Rp7.500.000 & Rp7.500.000 & Rp8.000.000 & Rp8.000.000 \\
\hline 2 & Rp10.000.000 & Rp15.000.000 & Rp15.000.000 & Rp22.500.000 & Rp14.252.904 & Rp22.252.904 \\
\hline 3 & Rp15.000.000 & Rp30.000.000 & Rp20.000.000 & Rp42.500.000 & Rp18.065.184 & Rp40.318.088 \\
\hline 4 & Rp288.767.000 & Rp318.767.000 & Rp243.767.000 & Rp286.267.000 & Rp358.807.420 & Rp399.125.508 \\
\hline 5 & Rp562.534.000 & Rp881.301.000 & Rp467.534.000 & Rp753.801.000 & Rp576.652.428 & Rp975.777.936 \\
\hline 6 & Rp756.301.000 & Rp1.637.602.000 & Rp725.061.782 & Rp1.478.862.782 & Rp716.209.000 & Rp1.691.986.936 \\
\hline 7 & Rp1.038.648.000 & Rp2.676.250.000 & Rp950.106.564 & Rp2.428.969.346 & Rp847.344.290 & Rp2.539.331.226 \\
\hline 8 & Rp1.278.832.233 & Rp3.955.082.233 & Rp1.074.388.297 & Rp3.503.357.643 & Rp1.132.547.546 & Rp3.671.878.772 \\
\hline 9 & Rp1.357.990.421 & Rp5.313.072.654 & Rp1.291.815.279 & Rp4.795.172.922 & Rp1.284.261.260 & Rp4.956.140.032 \\
\hline 10 & Rp1.429.224.128 & Rp6.742.296.781 & Rp1.358.028.985 & Rp6.153.201.907 & Rp1.330.500.626 & Rp6.286.640.658 \\
\hline 11 & Rp1.461.585.334 & Rp8.203.882.115 & Rp1.415.573.692 & Rp7.568.775.599 & Rp1.562.052.650 & Rp7.848.693.308 \\
\hline 12 & Rp1.493.946.540 & Rp9.697.828.655 & Rp1.429.262.692 & Rp8.998.038.290 & Rp1.513.311.510 & Rp9.362.004.818 \\
\hline 13 & Rp1.493.946.540 & Rp11.191.775.195 & Rp1.429.262.692 & Rp10.427.300.982 & Rp1.554.787.686 & Rp10.916.792.504 \\
\hline 14 & Rp1.550.040.012 & Rp12.741.815.207 & Rp1.493.985.104 & Rp11.921.286.086 & Rp1.618.882.060 & Rp12.535.674.564 \\
\hline 15 & Rp1.606.133.483 & Rp14.347.948.690 & Rp1.550.078.576 & Rp13.471.364.662 & Rp1.512.756.500 & Rp14.048.431.064 \\
\hline 16 & Rp1.886.600.841 & Rp16.234.549.530 & Rp1.606.172.047 & Rp15.077.536.709 & Rp1.714.264.000 & Rp15.762.695.064 \\
\hline
\end{tabular}

Table 4 shows the results of PV EV AC calculations using a dashboard obtained from the schedule plan, budget plan and weekly progress input processes. The PV EV AC value will be used as the basis for calculations in the next worksheet.

\subsection{S Curve}

The $\mathrm{S}$ curve is a graph or mathematical illustration that accurately represents the cumulative data that is appropriate for a project or job [8]. The data displayed will show the $\mathrm{X}$ and $\mathrm{Y}$ axes, where the $\mathrm{X}$ axis shows the time data (weeks) and the $\mathrm{Y}$ axis shows the cost data (rupiah). In this research, the S-Curve was obtained as shown in Figure 7 below: 


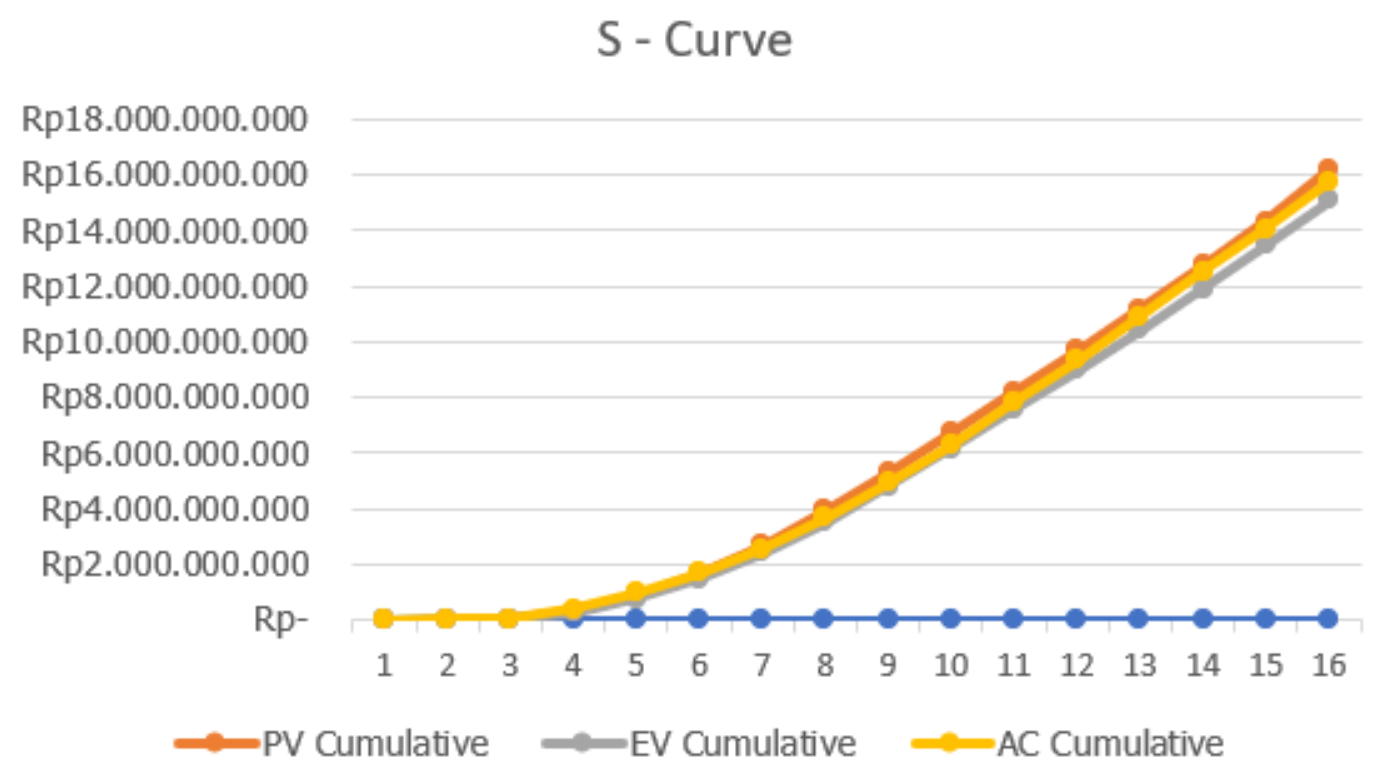

Figure 3-S - Curve

Figure 3 shows the results of the S - Curve based on the PV EV AC value using the dashboard. It can be seen that the $\mathrm{EV}$ and $\mathrm{AC}$ values are not always below the PV value, this is caused by several factors, namely the planning process is less detailed, several times the image changes in the project shop drawing process and incompatibility in the material procurement process.

\subsection{Calculation of Variance}

The calculation of variance is a calculation to get the SV and CV values using the spreadsheet-based dashboard which is carried out according to the earned value management equations. The following are the results of the calculation of SV and CV in the 1st week to 16 th week period:

Table 5 - Variance Calculation

\begin{tabular}{|c|c|c|}
\hline \multicolumn{3}{|c|}{ Variance } \\
\hline $\begin{array}{c}\text { SV } \\
\text { (Rp) }\end{array}$ & & $\begin{array}{c}\text { CV } \\
(\mathrm{Rp})\end{array}$ \\
\hline $\operatorname{Rp} \quad 2.500 .000$ & $-R p$ & 500.000 \\
\hline $\mathrm{Rp} \quad 5.000 .000$ & $\mathrm{Rp}$ & 747.096 \\
\hline $\mathrm{Rp} \quad 5.000 .000$ & $\mathrm{Rp}$ & 1.934 .816 \\
\hline -Rp 45.000.000 & $-R p$ & 115.040 .420 \\
\hline -Rp 95.000.000 & $-\mathrm{Rp}$ & 109.118 .428 \\
\hline -Rp 31.239.218 & $\mathrm{Rp}$ & 8.852 .782 \\
\hline -Rp 88.541.436 & $\mathrm{Rp}$ & 102.762 .274 \\
\hline -Rp204.443.936 & $-\mathrm{Rp}$ & 58.159 .249 \\
\hline -Rp 66.175 .142 & $\mathrm{Rp}$ & 7.554 .019 \\
\hline -Rp 71.195 .142 & $\mathrm{Rp}$ & 27.528 .359 \\
\hline -Rp 46.011 .642 & $-\mathrm{Rp}$ & 146.478 .958 \\
\hline -Rp 64.683 .848 & $-\mathrm{Rp}$ & 84.048.818 \\
\hline -Rp 64.683 .848 & $-R p$ & 125.524 .994 \\
\hline -Rp 56.054.907 & $-\mathrm{Rp}$ & 124.896 .956 \\
\hline -Rp 56.054.907 & $\mathrm{Rp}$ & 37.322 .076 \\
\hline -Rp280.428.793 & $-R p$ & 108.091 .953 \\
\hline
\end{tabular}


Table 5 shows the results of variance calculation consisting SV and CV values. It can be seen that the value of SV and $\mathrm{CV}$ at week 16 is negative where the SV value is $-\mathrm{Rp} .280 .428 .793$ and CV value is -Rp.108.091.953, which means that the project time has been delayed and the project cost has increased.

\subsection{Calculate of Performance Index}

The calculation of the performance index is a calculation to get the SPI and CPI values using the spreadsheet-based dashboard which is carried out according to the earned value management equations. The following are the results of the calculation of SPI and CPI in the 1st week to 16th week period:

\begin{tabular}{cc} 
Table 6- Performance Index Calculation \\
\cline { 2 - 2 } Performance Index \\
\hline SPI & CPI \\
\hline 1,50 & 0,94 \\
1,50 & 1,05 \\
1,33 & 1,11 \\
0,84 & 0,68 \\
0,83 & 0,81 \\
0,96 & 1,01 \\
0,91 & 1,12 \\
0,84 & 0,95 \\
0,95 & 1,01 \\
0,95 & 1,02 \\
0,97 & 0,91 \\
0,96 & 0,94 \\
0,96 & 0,92 \\
0,96 & 0,92 \\
0,97 & 1,02 \\
0,85 & 0,94 \\
\hline
\end{tabular}

Table 6 shows the results of performance index calculation consisting of the SPI and CPI values. It can be seen that the SPI and CPI values at week 16 are below one $(<1)$ where the SPI value is 0.85 and the CPI value is 0.94 , which means that the project time has been delayed and the project costs have increased.

\subsection{Calculations of Project Costs and Time Estimated}

Calculation of the estimated cost and project time using the spreadsheet-based dashboard which is carried out according to the earned value management equations for the 1 st week to the 16th week got the following results:

1. Calculation of Second Assumption Cost Estimation

The calculation of the estimated completion (EAC) of the first assumption is done by looking at the current CPI value. The following are the results of the estimated final project costs and the remaining costs of the first assumption project work:

Table 7 - EAC First Assumption Calculation

\begin{tabular}{cccc}
\hline \multicolumn{3}{c}{ Cost Estimate } \\
\hline \multicolumn{2}{c}{$\begin{array}{c}\text { EAC } \\
(\mathbf{R p})\end{array}$} & & $\begin{array}{c}\text { ETC } \\
(\mathbf{R p})\end{array}$ \\
\hline Rp 2.316 .872 .745 & Rp 2.308 .872 .745 \\
Rp 2.063 .885 .301 & Rp 2.049 .632 .397 \\
Rp 1.961 .940 .583 & Rp 1.943 .875 .399 \\
Rp 3.197.127.528 & Rp 2.838 .320 .108
\end{tabular}




\begin{tabular}{|c|c|c|}
\hline Rp 2.679.010.297 & $\mathrm{Rp}$ & 2.102 .357 .869 \\
\hline Rp 2.145.547.911 & $\mathrm{Rp}$ & 1.429 .338 .911 \\
\hline Rp 1.937.140.164 & $\mathrm{Rp}$ & 1.089 .795 .874 \\
\hline Rp 2.289.647.528 & $\mathrm{Rp}$ & 1.157.099.982 \\
\hline Rp 2.159.366.812 & $\mathrm{Rp}$ & 875.105 .552 \\
\hline Rp 2.128.038.597 & $\mathrm{Rp}$ & 797.537.971 \\
\hline Rp 2.396.826.746 & $\mathrm{Rp}$ & 834.774 .096 \\
\hline Rp 2.299.798.227 & $\mathrm{Rp}$ & 786.486 .717 \\
\hline Rp 2.362.830.085 & $\mathrm{Rp}$ & 808.042 .399 \\
\hline Rp 2.353.652.810 & $\mathrm{Rp}$ & 734.770 .750 \\
\hline Rp 2.119.770.144 & $\mathrm{Rp}$ & 607.013 .644 \\
\hline Rp 2.318.243.755 & $\mathrm{Rp}$ & 603.979 .755 \\
\hline
\end{tabular}

Table 7 shows the results of the estimated cost calculations first assumptions consisting of EAC and ETC. It can be seen that if the actual conditions (week 16) are in accordance with the first assumption, the cost required to complete the project (EAC) is Rp. 2,318,243,755 and the cost required to complete the remaining project work (ETC) is Rp. 603.979.755.

2. Calculation of Second Assumption Cost Estimation

The calculation of the estimated completion (EAC) of the second assumption is carried out by looking at the level of the budgeted value. The following are the results of the estimated final project costs and the remaining costs of the second assumption project work:

Table 8 - AC Second Assumption Calculation

\begin{tabular}{|c|c|c|}
\hline \multicolumn{3}{|c|}{ Cost Estimate } \\
\hline $\begin{array}{l}\text { EAC } \\
\text { (Rp) }\end{array}$ & & $\begin{array}{l}\text { ETC } \\
\text { (Rp) }\end{array}$ \\
\hline Rp 2.172.568.198 & $\mathrm{Rp}$ & 2.164.568.198 \\
\hline Rp 2.171.321.102 & $\mathrm{Rp}$ & 2.157 .068 .198 \\
\hline Rp 2.170.133.382 & $\mathrm{Rp}$ & 2.152 .068 .198 \\
\hline $\operatorname{Rp} 2.287 .108 .618$ & $\mathrm{Rp}$ & 1.928.301.198 \\
\hline $\operatorname{Rp} 2.281 .186 .626$ & $\mathrm{Rp}$ & 1.704 .534 .198 \\
\hline Rp 2.163.215.416 & $\mathrm{Rp}$ & 1.447 .006 .416 \\
\hline Rp 2.069.305.924 & $\mathrm{Rp}$ & 1.221 .961 .634 \\
\hline Rp 2.230.227.447 & $\mathrm{Rp}$ & 1.097.679.901 \\
\hline Rp 2.164.514.179 & $\mathrm{Rp}$ & 880.252 .919 \\
\hline Rp 2.144.539.839 & $\mathrm{Rp}$ & 814.039 .213 \\
\hline Rp 2.318.547.156 & $\mathrm{Rp}$ & 756.494 .506 \\
\hline $\operatorname{Rp} 2.256 .117 .016$ & $\mathrm{Rp}$ & 742.805 .506 \\
\hline Rp 2.297.593.192 & $\mathrm{Rp}$ & 742.805 .506 \\
\hline Rp 2.296.965.154 & $\mathrm{Rp}$ & 678.083 .094 \\
\hline Rp 2.134.746.122 & $\mathrm{Rp}$ & 621.989 .622 \\
\hline Rp 2.280.160.151 & $\mathrm{Rp}$ & 565.896 .151 \\
\hline
\end{tabular}


Table 8 shows the results of the estimated cost calculations second assumptions consisting of EAC and ETC. It can be seen that if the actual conditions (week 16) are in accordance with the second assumption, the cost required to complete the project (EAC) is Rp. 2,280,160,151 and the cost required to complete the remaining project work (ETC) is Rp. 565,896,151.

3. Calculation of the Third Assumption Cost Estimate

Estimated completion calculation (EAC) is carried out by considering the SPI and CPI value factors. In this method, the ratio of the SPI and CPI values will be used. In this calculation, the ratio is assumed to be $100 \%$ because it is not provided by the company. The following are the results of the estimated final project costs and the remaining costs of the third assumption project work:

Table 9 - EAC Third Assumption Calculation

\begin{tabular}{|c|c|c|}
\hline \multicolumn{3}{|c|}{ Cost Estimate } \\
\hline $\begin{array}{l}\text { EAC } \\
\text { (Rp) }\end{array}$ & & $\begin{array}{l}\text { ETC } \\
\text { (Rp) }\end{array}$ \\
\hline Rp 1.547.248.496 & $\mathrm{Rp}$ & 1.539 .248 .496 \\
\hline Rp 1.380.674.502 & $\mathrm{Rp}$ & 1.366 .421 .598 \\
\hline Rp 1.475.971.733 & $\mathrm{Rp}$ & 1.457 .906 .549 \\
\hline Rp 3.721.088.544 & $\mathrm{Rp}$ & 3.362 .281 .124 \\
\hline Rp 3.106.196.336 & $\mathrm{Rp}$ & 2.529.543.908 \\
\hline Rp 2.207.130.842 & $\mathrm{Rp}$ & 1.490 .921 .842 \\
\hline Rp 2.038.699.394 & $\mathrm{Rp}$ & 1.191 .355 .104 \\
\hline Rp 2.509.830.562 & $\mathrm{Rp}$ & 1.377 .283 .016 \\
\hline Rp 2.204.195.384 & $\mathrm{Rp}$ & 919.934 .124 \\
\hline Rp 2.169.849.803 & $\mathrm{Rp}$ & 839.349 .177 \\
\hline Rp 2.423.960.146 & $\mathrm{Rp}$ & 861.907 .496 \\
\hline Rp 2.335.392.095 & $\mathrm{Rp}$ & 822.080 .585 \\
\hline Rp 2.399.399.494 & $\mathrm{Rp}$ & 844.611 .808 \\
\hline Rp 2.381.221.697 & $\mathrm{Rp}$ & 762.339 .637 \\
\hline Rp 2.141.721.349 & $\mathrm{Rp}$ & 628.964 .849 \\
\hline Rp 2.423.695.294 & $\mathrm{Rp}$ & 709.431 .294 \\
\hline
\end{tabular}

Table 9 shows the results of the estimated cost calculations third assumptions consisting of EAC and ETC. It can be seen that if the actual condition (week 16) is in accordance with the third assumption, the cost required to complete the project (EAC) is Rp. 2,423,695,294 and the cost needed to complete the remaining project work (ETC) is Rp. 709,431,294.

4. Calculation of Time Estimate

Time estimate calculation is a calculation carried out to find out the estimated time for project completion using a spreadsheet-based dashboard with an equation that has been determined at the time of dashboard design. The following is the result of the times estimate calculation in the 1st week to 16th week period: 
Table 10 - Time Estimate Calculation

\begin{tabular}{c}
\hline Time Estimate \\
\hline 12 \\
12 \\
21 \\
22 \\
19 \\
20 \\
21 \\
19 \\
19 \\
19 \\
19 \\
19 \\
19 \\
19 \\
21
\end{tabular}

Table 10 shows the results of the estimated time (TE). It can be seen that in the 16th week the estimated time obtained to complete the project is 21 weeks or there is an additional time of 3 weeks from the planning time.

\section{CONCLUSION}

This research proves that earned value management method can use to analyze project performance with cost and time aspect. The result of construction project performance using spreadsheet-based dashboard as a tool is still not good, the data shows that the project performance is in the poor project status, where at week 16 the CPI and SPI values are 0.94 and 0.85. Both values can be interpreted that the costs incurred are greater than planning and the implementation time is longer than planning. The result of construction project estimated completion costs or EAC at week 16 is Rp. 2.423.695.294 with the estimated completion time is 21 weeks or there is an additional 3 weeks of completion time. This delay was caused by various factors, namely project planning that was less detailed, changes to the project shop drawings and incompatibility of material delivery times.

By doing this research, will provide many benefits for contractor companies in assisting the process of project monitoring and controlling by knowing the project performance. By knowing the performance of the project the company can find out the actual condition of the project and by knowing the estimated time and cost of project completion, the company can easily make decisions to evaluate improvements in project completion.

\section{Disclaimer}

The authors whose names are written certify that they have no conflict of interest.

\section{REFERENCES}

[1] PMI. (2017). Project Management Body of Knowledge. Newtown Square, Pennsylvania: 14 Campus Boulevard.

[2] Putu, I. A., Wirahaji, I. B., \& Wijaya, I. H. (2019). Pengendalian Proyek dengan Earned Value Management (EVM) pada Proyek Pemeliharaan Jalan Provinsi Denpasar - Simpang Pesanggaran. Jurnal Widya Teknik Vol 13 No 02.

[3] Wiyana, Y. E. (2012). Analisis Kegagalan Konstruksi dan Bangunan dari Perspektif Faktor Teknis. Wahana Teknik Sipil Vol. 17, 77 - 78.

[4] Mulcahy, R. (2018). PMP Exam Prep Ninth Edition. United State of America: RMC Publications.

[5] Widiningrum, A., Haryono, I., \& Pratami, D. (2018). Analisis Kinerja Proyek dengan Metode Earned Value Management pada Proyek Shutdown STO Tanjungsari. e-Proceeding of Engineering : Vol.5, No.3.

[6] Maromi, M. I., \& Indryani, R. (2015). Metode Earnd Value untuk Analisa Kinerja Biaya dan Waktu Pelaksanaan pada Proyek Pembangunan Condotel De Vasa Surabaya. Jurnal Teknik ITS Vol 4 No 1, 55 - 56.

[7] Sediyanto, \& Hidayat, A. (2017). Analisa Kinerja Biaya dan Waktu pada Pelaksanaan Proyek Konstruksi dengan Metode Earned Value (Studi Kasus Proyek Konstruksi Mall dan Hotel X di Pekanbaru). Jurnal Ilmu Teknik dan Komputer.

[8] Priyo, M., \& Indraga, K. F. (2015). Analisis Kinerja Biaya dan Jadwal Terpadu dengan Konsep Earned Value Method (Studi Kasus: Proyek Pembangunana Gedung). JURNAL ILMIAH SEMESTA TEKNIKA Vol. 18, No. 2. 
[9] Briandhito, C., Puspita, I. A., \& Widyasthana, S. (2019). Analisis Kinerja Biaya dan Waktu Menggunakan Metode Earned Value Manajemen dan TCTO untuk Mengoptimalkan Biaya dan Waktu pada Proyek Summarecon Bandung. e-Proceeding of Engineering : Vol.6, No.2.

[10] Hafizh, A. (2018). Analisa Biaya dan Waktu Proyek dalam Proses Kinerja dengan Menggunakan Metode Earned Value. 11 - 17.

[11] Hidayatullohi, T. (2019). Earned Value Pelaksanaan Proyek Pembangunan Kantor Denma Seskoad TNI AD Ditinjau dari Kinerja Waktu Menggunakan Ms. Project. Jurnal IKRA-ITH Teknologi Vol 3 No 1.

[12] Mualim, P. P., Pratami, D., \& Bay, A. F. (2020). Monitoring Proyek Ducting FO Kawasan Tahap III Summarecon Bandung Menggunakan Metode Earned Value Management. Seminar Nasional Teknik Industri Universitas Gadjah Mada.

[13] Nicholas, J. M., \& Steyn, H. (2012). Project Management for Engineering, Business and Technology. London and New York: Routledge.

[14] Rani, H. A. (2016). Manajemen Proyek Konstruksi. Yogyakarta: Deepublish.

[15] Wahyuni, E., \& Hendrawan, B. (2018). Analisis Kinerja Proyek "Y" Menggunakan Metode Earned Value Management (Studi Kasus di PT Asian Sealand Engineering). Journal of Applied Business Administration Vol 2, No 1. 